International Journal of Environment, Agriculture and Biotechnology
Vol-6, Issue-3; May-Jun, 2021
JUAB
$\begin{gathered}\text { Journal Home Page Available: } \text { https://ijeab.com/ } \\ \text { Journal DOI: } 10.22161 / \text { ijeab }\end{gathered}$

Article

Peer-Reviewed Journal

\title{
Efficacy of different fungicides against the in-vitro growth of Pyricularia oryzae causing Rice blast disease
}

\author{
Karuna Kafle $^{1 *}$, Abichal Poudel ${ }^{1}$, Shrinkhala Manandhar ${ }^{2}$, Nirmal Adhikari ${ }^{1}$
}

${ }^{1}$ Purbanchal University, GP Koirala College of Agriculture and Research Center (GPCAR)

${ }^{2}$ Scientist (S1) - National Plant Pathology Research center, Nepal Agricultural Research Council

*Corresponding author- kaflay71@gmail.com

Received: 09 Apr 2021; Received in revised form: 23 May 2021; Accepted: 07 Jun 2021; Available online: 17 Jun 2021

(C)2021 The Author(s). Published by Infogain Publication. This is an open access article under the CC BY license

(https://creativecommons.org/licenses/by/4.0/).

\begin{abstract}
Rice blast disease caused by Pyricularia oryzae is a major threat to the farmers as the disease severity may lead upto $80 \%$ crop loss in severe conditions. A laboratory experiment was conducted at National Plant Pathology Research center of NARC, Khumaltar,Lalitpur for testing the efficacy of different fungicides adopting poisoned food method against the pathogen Pyricularia oryzae causing rice blast disease. The experiment was carried out in a completely randomized design with 10 treatments including control following 3 replications of each. Two concentrations (50 ppm and $100 \mathrm{ppm}$ ) each of different fungicides viz. Dithane M-45 (Mancozeb 75\%W.P), Bavistin (Carbendazim 50 \% W.P), Antracol (Propineb 70\%W.P) , Diamethmorph 50\%WP, Sectin (Fenamidone 10\%+ Mancozeb 50\%W.G),Protector ZN ( Chlorothalonil 75\% W.P), Safaya (Carbendazim 12\%+ mancozeb63\% W.P) , Nativo 75\% W.G (Tebuconazole 50\%+ Trifloxystrobin25\%W.G) and Topcare (Azoxystrobin 50\% W.D.G) were evaluated against the growth of the pathogen. Results showed that lower concentration (50ppm) of Bavistin and Safaya fully inhibited the growth of the pathogen while Nativo at higher concentration (100 ppm) was shown to exhibit $100 \%$ inhibition of the pathogen. The fungicides significantly inhibited the mycelia growth with the increase in concentration of fungicide. However, the fungicides found effective for mycelia inhibition of P.oryzae should be further tested in field conditions to verify their efficacy as well the optimum dozes of fungicide should be re-evaluated.
\end{abstract}

Keywords-Efficacy, Fungicide, Inhibition, in-vitro, Poisoned food technique.

\section{INTRODUCTION}

Rice (Oryza sativa $\mathrm{L}$.) is the main cereal crop of the world and is a staple food for more than a half population of the world(Ahmad et al., 2020, Singh et al., 2019).More than 2.7 billion people of the world have rice as a major source for their food (Kulmitra et al., 2017). Rice is also the major source of food for the people of Nepal. Rice, maize and wheat are the three major food crops grown in different parts of Nepal. However, rice has the highest productivity in Nepal. Rice is grown in all three ecological belts of Nepal ranging from the plain terai to the high Himalayan region (Joshi et al., 2011).The terai region of Nepal has high productivity of rice contributing to $70 \%$ total domestic production of the country.

The productivity of rice in the country is hindered by many factors among which disease is the prime one. The crop loss due to diseases and pest is recorded $37 \%$ annually in rice (Moktan et al., 2021). Blast is the major fungal disease attacking the rice plant and is caused by the fungus Pyricularia oryzae. This disease is prevalent in humid areas in all the rice growing region of the world as the conidia are not developed below $88 \%$ R.H (Neelakanth et al., 2017) .P.oryzae, the cause of rice blast disease was reported for the first time in China. In Nepal, it was reported for the first time from Thimi, Bhaktapur in 
1964(Neupane \& Kiran Bhusal, 2021).The fungus attacks all the above ground parts of rice plant at all growth stages viz., leaf, collar, node, internodes, base or neck and other parts of the panicle and sometimes the leaf sheath. A typical blast lesion on a rice leaf is spindle shaped, gray at the centre, and has a dark border (Kulmitra et al., 2017). Rice blast disease may cause crop loss ranging up to 80 per cent depending upon part of the plant infected (Neupane \& Kiran Bhusal, 2021).

Depending on the host affected, it shows variable symptoms as leaf and leaf sheath blast, nodal blast, collar blast, neck blast and panicle blast. Planting of the resistant varieties, use of different fungicides, timely application of fertilizers are the most commonly used method for controlling the disease development. However, application of fungicide has been found quick and effective for mitigating the fungal development. Seed treatment and foliar application of different fungicides have been found effective in controlling the disease (Magar et al., 2015). Rice blast can be effectively controlled upto 40-84\% by application of different fungicides mostly in the temperate and subtropical rice growing regions of the world. (Pandey,2016). To find out the most effective fungicide against the disease, a laboratory experiment was conducted in National Plant Pathology Research Centre, NARC, Khumaltar.

\section{MATERIALS AND METHOD}

A laboratory experiment was conducted at NARC, Khumaltar with 10 treatments (50 ppm and $100 \mathrm{ppm}$ ) including control and experiment was arranged in completely randomized Design (CRD) to test the efficacy of different fungicides against the in-vitro growth of pathogen $P$. oryzae causing rice blast disease.The experiment was carried out fromJuly 2020 to October 2020.

Culture of P.oryzae, previously isolated from rice, Mulpani was obtained from the National Plant Pathology Research Centre NARC, Khumaltar and pure culture was maintained on potato dextrose agar (PDA) under incubated condition at $25^{\circ} \mathrm{C}$ for 7 days

Different fungicides (Table. 1) were evaluated in-vitro for testing their efficacy to inhibit the mycelium growth of fungal pathogen P.oryzae. Stock solution was prepared for each fungicide by diluting $1 \mathrm{gm}$ in $100 \mathrm{ml}$ of distilled water and required amount was incorporated into the conical flask containing Oat meal agar to get 50ppm and 100ppm concentration and mixed thoroughly before autoclaving.

After autoclaving, $20 \mathrm{ml}$ of the poisoned media was poured aseptically into the sterilized petri plates each of 9 $\mathrm{cm}$ diameter under laminar air flow chamber and allowed to solidify. As for control, only OMA media was used without addition of any fungicide. $5 \mathrm{~mm}$ radial disc of the pathogen from the 7 days old culture plate was placed on the center of the petri plate containing OMA media and incubated at $24^{\circ} \mathrm{C}$.

The diameter of the pathogen was taken from two directions after 2 day after inoculation (DAI) and recorded for 10 days after. Percent inhibition of fungal growth was calculated using the formula (Vincent, 1947).

$$
I \%=\frac{C-T}{C} x 100
$$

Where,

$\mathrm{C}=$ growth of pathogen in control plate (without fungicide)

$\mathrm{T}=$ growth of pathogen in treated plate (with fungicide)

$\mathrm{I} \%=$ Percentage growth inhibition

Data was entered in MS-Excel (2007) and subjected to ANOVA with the help of R-studio (R-version 3.5.3 statistical data analysis package). Mean comparison among significant variables was carried out by Fisher-LSD test at $5 \%$ level of significance. MS-Excel (2007) was used for construction of graph and tables.

Table. 1: Treatments with different fungicides used in the study

\begin{tabular}{|l|l|l|l|}
\hline S.N & Treatment & Trade name & Composition \\
\hline 1 & T1 & Dithane M-45 & Mancozeb 75\%W.P \\
\hline 2 & T2 & Bavistin & Carbendazim 50\% W.P \\
\hline 3 & T3 & Dimethomorph & $\begin{array}{l}\text { Dimethomorph } \\
50 \% \text { W.P }\end{array}$ \\
\hline 4 & T4 & Protector ZN & Chlorothalonil 75\% W.P \\
\hline 5 & T5 & Safaya & $\begin{array}{l}\text { Carbendazim 12\%+ } \\
\text { Mancozeb63\%W.P }\end{array}$ \\
\hline 6 & T6 & Nativo & $\begin{array}{l}\text { Tebuconazole } \\
\text { Trifloxystrobin25\%W.G }\end{array}$ \\
\hline 7 & T7 & Antracol & Propineb70\% W.P \\
\hline 8 & T8 & Topcare & Azoxystrobin50\%W.DG \\
\hline 9 & T9 & Sectin & $\begin{array}{l}\text { Fenamidone } \\
\text { Mancozeb 50\%W.G }\end{array}$ \\
\hline 10. & T10 & Control & - \\
\hline
\end{tabular}




\section{RESULTS AND DISCUSSION}

\subsection{Effect of different fungicides in inhibiting the growth of P.oryzae at 50ppm and $100 \mathrm{ppm}$}

Different fungicides at $50 \mathrm{ppm}$ and $100 \mathrm{ppm}$ were tested against the pathogen P.oryzae following the poisoned food technique and their efficacy ispresented in Table 2. The table shows that the fungal mycelia gradually increased in both treated and control plate with the increase in incubation period of the pathogen. All the 9 fungicides of different concentrations (50 and $100 \mathrm{ppm}$ ) visibly inhibited mycelial growth over control during the study (Table 2).

Bavistin and Safaya were found most effective in inhibiting the mycelia growth among the tested 9 fungicides. Bavistin, Safaya and Nativo were individually effective against the pathogen as they showed maximum inhibition of the mycelia growth. At lower concentration (50ppm), Bavistin and Safaya showed complete inhibition of the mycelia growth whereas at higher concentration(100ppm), Bavistin, Safaya along with Nativo showed complete inhibition of the mycelia. They were significantly superior over other fungicides and on par with each other. These were followed by Azoxystrobin and Sectin (100ppm)with more than $70 \%$ mycelia inhibition.

Dithane M-45, Dimethomorph and Chlorothalonil showed low inhibition of the fungal mycelia as compared to above fungicides. The fungicide Protector $\mathrm{ZN}$ was ineffective against the pathogen with least inhibition percentage. It was noted that the mycelial growth was decreased with the increase in concentration of fungicides.

Table 2. Effect of different fungicides on inhibition of mycelial growth of Pyricularia after nine days of inoculation

\begin{tabular}{lcc}
\hline \multirow{2}{*}{ Treatment } & \multicolumn{2}{c}{ Inhibition percentage (\%) } \\
\cline { 2 - 3 } & $100.00^{\mathrm{a}} \pm 0.00$ & $100.00^{\mathrm{a}} \pm 0.00$ \\
\hline Bavistin & $100.00^{\mathrm{a}} \pm 0.00$ & $100.00^{\mathrm{a}} \pm 0.00$ \\
Safaya & $85.99^{\mathrm{b}} \pm 0.64$ & $100.00^{\mathrm{a}} \pm 0.00$ \\
Nativo & $70.42^{\mathrm{c}} \pm 1.72$ & $78.29 \mathrm{~b}^{\mathrm{b}} \pm 3.51$ \\
Topcare & $45.44^{\mathrm{d}} \pm 3.59$ & $72.82^{\mathrm{c}} \pm 3.41$ \\
Sectin & $50.40^{\mathrm{d}} \pm 5.98$ & $47.66^{\mathrm{d}} \pm 5.31$ \\
Antracol & $34.28^{\mathrm{e}} \pm 3.05$ & $37.19^{\mathrm{e}} \pm 3.31$ \\
Dimethomorph & $26.80^{\mathrm{f}} \pm 4.81$ & $26.38^{\mathrm{f}} \pm 2.17$ \\
Dithane M-45 & $13.93^{\mathrm{g}} \pm 2.12$ & $24.78^{\mathrm{f}} \pm 3.10$ \\
Protector ZN & 5.39 & 5.03 \\
\hline LSD 0.05 & 5.37 & 4.49 \\
CV (\%) & &
\end{tabular}

F-Test

$* *$

$* *$

CV: Coefficient of Variation; **: Significant at $1 \%$ level of significance; LSD: Least Significant Difference; Values with same letters in a column are not significantly different at $5 \%$ level of significance by Fisher-LSD test and figure \pm indicate standard error values.

\subsection{Comparison of growth of P.oryzae at $50 \mathrm{ppm}$ and 100ppm}

Pathogen at different concentration 50 and 100ppm showed different growth from $1^{\text {st }}$ to $9^{\text {th }}$ day after inoculation (Fig.1 and 2). At 50 ppm, Bavistin and Safaya exhibited no growth of the fungal pathogen till the $9^{\text {th }}$ day after inoculation.

Slow growth of the pathogen was observed in the treated plate of Nativo during the early days and the growth of pathogen was not observed from $5^{\text {th }}$ day of inoculation. Similar growth of mycelia was observed in case of Sectin and Antracol treated plates. Dithane M-45 and Dimethomorph also exhibited the similar growth pattern of the pathogen .The growth of pathogen in Protector $\mathrm{ZN}$ suddenly increased on the $9^{\text {th }}$ day whereas the growth was similar in other days. Increase in growth of the pathogen was seen every day in Control plate until the plate was fully covered.

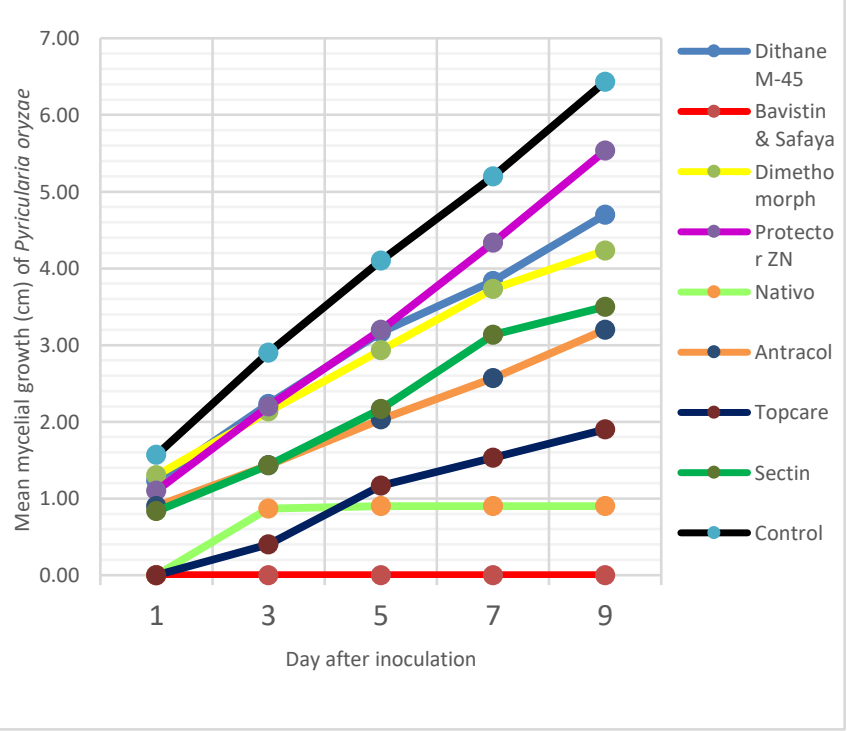

Fig. 1: Effect of different fungicides at 50ppm on mycelial growth of $P$. oryzae at different days after inoculation

At 100 ppm, Bavistin, Safaya and Nativo showed no growth of pathogen until the 9th day after inoculation. Sectin and Topcare at 100ppm showed similar trend of the pathogen growth along with Protector $\mathrm{ZN}$ and Dithane M45. Antracol exhibited gradual increase in fungal mycelium from the $1^{\text {st }}$ day of inoculation. Control visibly 
exhibited the increasing growth of the pathogen every day until full growth on the plate.

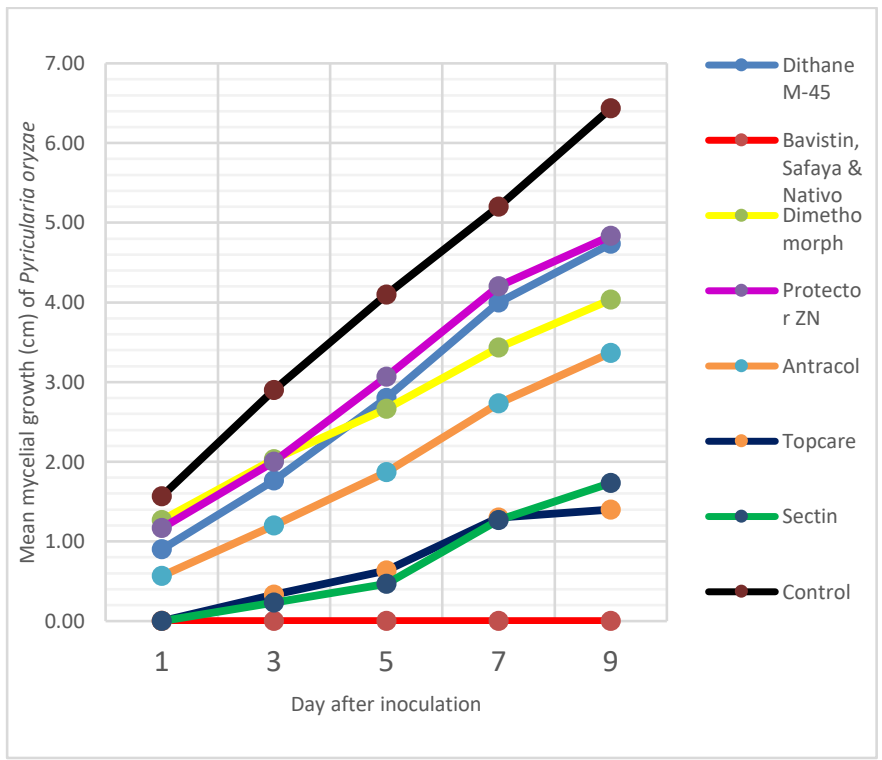

Fig.2: Effect of different fungicides at 100ppm on mycelial growth of P.oryzae at different days after inoculation

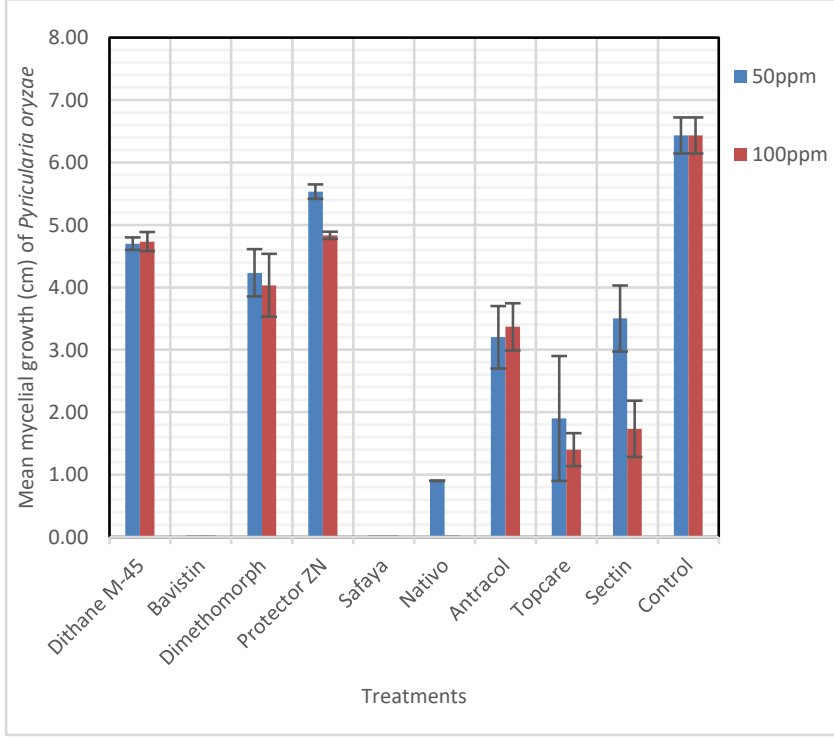

Fig.3: Mean mycelial growth $(\mathrm{cm})$ of $P$. oryzae in $50 \mathrm{ppm}$ and 100 ppm of different fungicides at $9^{\text {th }}$ day after inoculation

Fungicide at different concentration 50ppm and 100ppm showed different growth of mycelium at $9^{\text {th }}$ day of inoculation (Fig. 3). Growth of fungal mycelium in treated plate of Dithane M-45, Dimethomorph and Antracol were similar in both concentrations (50ppm and 100ppm). Bavistin and Safaya both showed no growth of pathogen even on the $9^{\text {th }}$ day. Nativo at $50 \mathrm{ppm}$ concentration showed slight growth of pathogen and at 100ppm exhibited no growth at all. The growth of pathogen was relatively lower in higher concentration (100ppm) of Protector ZN and Sectin. The growth of mycelia is similar in both concentrations of Antracol. Control on the $9^{\text {th }}$ day of inoculation showed more growth of pathogen as compared to that of the treated plates.

Different concentration of the tested fungicides showed variation in the growth of fungal mycelium. Experiment shows that the highest inhibition of the mycelia was observed in the treated plate of Bavistin and Safaya. This result is in accordance with the finding of Konda et al., 2016 and Neelakanth et al., 2017who found 100\% inhibition of the mycelia growth of $P$. oryzae at different concentrations of chemical composition present in Safaya and Bavistin, respectively. From the experiment, it is recorded that Nativo at higher concentration has greatly inhibited the growth of fungal mycelium. Kulmitra et al., 2017 and Singh et al., 2019also recorded that Tebuconazole $50 \%+$ Trifloxystrobin $25 \%$ (WG) was found to be the most effective fungicide against the leaf blast disease.

The study shows that increasing the concentration of Azoxystrobin can increase the inhibition percentage of the pathogen. In our experiment the inhibition $\%$ of Azoxytrobin was found to be $70 \%$ at 50ppm which increased to $78 \%$ at $100 \mathrm{ppm}$. This is in accordance with Neelakanth et al., 2017 who recorded that the inhibition percentage of pathogen was increased with increase in concentration of Azoxystrobin.

DithaneM-45 has been reported effective against P.oryzae for seed treatment Konda et al., 2016 and Hajano et al., 2012. However, in our in vitro experiment, it was not found effective. Dithane could be effective as a protectant rather than for control of the disease once the pathogen has invaded.

\section{CONCLUSION}

The use of different chemical fungicides have been found effective to control various plant diseases. The treatments used in our experiment are easily available in the market. Farmers apply same fungicide for various type of fungal diseases and our findings show that there is difference among the fungicides in controlling the fungal growth.Same concentration of these fungicides is not equally effective against the pathogen.Results of this study show that rice blast can be effectively controlled by application of different fungicides. From the experiment, it is concluded that Bavistin (Carbendazim 50\% W.P), Safaya(Carbendazim12\%+Mancozeb63\%W.P) are the most effective ones among the tested fungicides with cent percent inhibition of mycelia growth. Nativo (Tebuconazole 50\%+ Trifloxystrobin25\%W.G) is also 
effective against the pathogen $P$. oryzae at higher concentration. The percent of inhibition of pathogen is increased with increasing concentration of fungicides. Further, green house trials and application of these treatments in infected host plants should be carried out to find their effectiveness under field condition.

\section{ACKNOWLEDGMENT}

We would like to thank PU, GPCAR for providing the platform and financial support. Also, we would like to thank National Plant Pathology Research Centre, NARC for laboratory access and all the helping hands for their support and guidance.

\section{CONFLICT OF INTEREST}

Authors declare no conflict of interest regarding the publication of manuscript.

\section{REFERENCES}

[1] Ahmad, H. M., Shahid, M. I., Ali, Q., Awais Anjum, N., Ayyub, M., Ikram, A., Faisal, M., Ali, A., \& Palwasha, A. (2020). Efficacy of different fungicides against rice blast under field condition in rice crop. Journal of Global Innovations in Agricultural and Social Sciences, 8(1), 1518. https://doi.org/10.22194/JGIASS/8.882

[2] Hajano, j.-u.-d., a. Mubeen lodhi, mumtaz a. Pathan, m. Ali khanzada, \& g. Serwar shah. (2012). In-vitro evaluation of fungicides, plant extracts and bio-controlagents against rice blast pathogen Magnaporthe oryzae couch. Pak. J. Bot, 44(5), 4.

[3] Joshi, N. P., Maharjan, K., \& Piya, L. (2011). Production economics of rice in different development regions of Nepal. J Int Dev Coop, 17(1), 103-112. Journal of International Development and Cooperation, 17(1), 11.

[4] Konda, S., Nagaraja, Gowdra Nagamma, P.S. Sangeetha, \& Suresh Patil. (2016). In vitro Evaluation of Bio-agents and Fungicides Against Leaf Blast (Pyricularia setariae) in Foxtail Millet [Setaria italica (L.) Beauv.]. Journal of pure and applied microbiology, 10(1), 8 .

[5] Kulmitra, A. K., Sahu, N., Kumar, V. B. S., G., T. A., Ghosh, A., \& Gulnaz, Y. (2017a). In vitro evaluation of bio-agents against Pyricularia oryzae (Cav.) causing rice blast disease. Agricultural Science Digest - A Research Journal, 37(03). https://doi.org/10.18805/asd.v37i03.8989

[6] Magar, P. B., Acharya, B., \& Pandey, B. (2015). Use of chemical fungicides for the management of rice blast (Pyricularia grisea) disease at jyotinagar, chitwan, nepal. International Journal of Applied Sciences and Biotechnology, 3(3), 474-478. https://doi.org/10.3126/ijasbt.v3i3.13287

[7] Moktan, R., Aryal, A., Karki, S., Devkota, A. K., Acharya, B., Joshi, D., \& Aryal, K. (2021). Evaluation of different chemical fungicides against rice blast in field conditions. Journal of Agriculture and Natural Resources, 4(2), 295-302. https://doi.org/10.3126/janr.v4i2.33942

[8] Neelakanth , Sidde Gowda D. K, Chethana B. S., \& Parasappa H. H. (2017). In vitro and In vivo Evaluation of Fungicides Against Pyricularia oryzae Causing Blast of Rice. Int. J. Pure App. Biosci, 5(3).http://dx.doi.org/10.18782/2320-7051.3080

[9] Neupane, N. \& Kiran Bhusal. (2021). A Review of Blast Disease of Rice in Nepal. Journal of Plant Pathology \& Microbiology, 12(1). https://doi.org/10.35248/2157$\underline{7471.20 .12 .528}$

[10] Pandey, s. (2016). Effect of fungicides on leaf blast and grain yield of rice in kymore region of madhya pradesh in india . Bangladesh j. Bot., 45(2), 8.

[11] Singh, H. S., Kaushik, S. S., Chauhan, M. S., \& Negi, R. S. (2019). Efficacy of different fungicides against rice blast caused by Pyricularia oryzae (Cav.) under field condition in satna district of madhya pradesh. International Journal of Current Microbiology and Applied Sciences, 8(06), 63-69. https://doi.org/10.20546/ijcmas.2019.806.009

[12] Vincent, J. M. (1947). Distortion of fungal hyphæ in the presence of certain inhibitors. Nature, 159(4051),850-850. https://doi.org/10.1038/159850b0 